The Agriculturists 12(2): 126-136(2014) ISSN 2304-7321 (Online), ISSN 1729-5211 (Print)

\title{
Impacts of Rice-Prawn Farming System on Farm Productivity, Food Security and Poverty Alleviation in Bangladesh: A Case Study in Khulna District
}

\author{
Basanta Kumar Barmon* \\ Dept. of Economics, East West University, Jahurul Islam City, Aftabnagar, Dhaka-1212, Bangladesh \\ *Corresponding author and Email: bkbarmon@yahoo.com
}

Received: 19 February 2014

Accepted: 13 December 2014

\begin{abstract}
The present study was undertaken to assess the impacts of rice-prawn gher (RPG) system on farm productivity, food security and poverty reduction in Bangladesh. In this study, farm survey data, extracted from a comprehensive questionnaire from two study villages viz. Bilpabla (RPG farming) and Chanchra (year-round modern variety-YRMV) located in Khulna and Jessore district, respectively were analyzed deliberately. This study consists of a random selection of ninety farmers from Bilpabla Village and one-hundred farmers from Chanchra. The study indicates that RPG farming system has significant impacts on farm productivity. On an average, yield of modern variety (MV) was reasonably higher in RPG farming system than that of YRMV farming system. In addition, the households engaged in RPG farming system (Bilpabla Village) have simultaneously generated more household income and per capita income (more than twice), relative to YRMV farming system (Chanchra Village). Moreover, the households of Bilpabla are superior to those households residing in Chanchra in terms of physical, social and economic access (purchasing power) which permits them to acquire and consume well-balanced food as well as sufficient calorie intake. Therefore, the RPG farming system had significant impacts on food security and poverty reduction.
\end{abstract}

Keywords: Rice-prawn gher farming, year-round paddy farming, farm productivity, food security, poverty reduction, Bangladesh

\section{Introduction}

Introduced in the mid 1980s, rice-prawn gher (RPG) farming system is an indigenous farming system developed by the local farmers in southwestern Bangladesh. This farming system, locally known as gher revolution, (Kendrick, 1994) was diffused rapidly compared to green revolution in Bangladesh, mainly due to the use of indigenous natural resources at the early stage (Barmon et al., 2005).

Prior to the RPG farming, the southwest region experienced a period of severe environmental change during the 1960s and 1980s. During this time, devastated farmers were unable to produce any agricultural crops on fertile land due to permanent waterlog and increased saline water intrusion due to construction of embankments and polders (Kendrick, 1994). The initiation of the RPG farming system has positively altered cropping patterns, enabling farmers to produce prawn and modern varieties (MV) of paddy throughout the year.

There are a few studies that focus on the influence of RPG farming on labor demand (Barmon et al., 2004a), household income 
(Barmon et al. 2004b; 2004c), the impacts of shrimp gher farming on the environment (Asaduzamman, 1998; Aftabuzzaman, 1998; Nijera Kori, 1996; Bhattacharya et al., 1999; Rahman, 1998; Islam, 2003) and ecology (Datta, 2001; Islam, 2001) in the coastal region of Bangladesh.

Other studies conducted sporadic research on input use in MV paddy production under rice prawn gher farming (Barmon et al., 2008), economic evaluation on soil fertility for MV paddy production under RPG farming (Barmon, et al., 2007 and 2010), water productivity for MV paddy production (Barmon et al., 2008), history, along with present and future challenges of RPG farming (Ahmed et al., 2008a; 2008b; 2008c; and Barmon et al., 2005), women's participation in gher farming (Barmon et al., 2007) child labor participation in prawn fry collection (Ahmed et al., 2009), diversified economy and efficiencies in a 'blue-green revolution' (Rahman et al., 2011; Ahmed, 2010a; 2010b), gher revolution (Kendrick, 1994), livelihood analysis of prawn farmers and associated groups (Ahmed et al., 2008c), economic returns to prawn and shrimp farming (Islam et al., 2005), agrarian change and economic transformation (Ito, 2002; 2004), prawn and shrimp marketing (Ahmed et al., 2009; Islam, 2008), and energy productivity and efficiency of the RPG system (Rahman and Barmon, 2012). Ahmed et al., (2008a and 2009) and Chowdhury et al., (2006)), qualitatively discussed the sustainability of RPG farming system in southwest Bangladesh.

Ali (2004) conducted a research to depict the impacts of cultivation of high yielding variety (HYV) of rice on soil qualities and land degradation from 1985 to 2000 , in a village in southwestern Bangladesh and concluded that modern inputs, especially the chemical fertilizers and pesticides, showed negative impacts on soil quality and land degradation. Similar conclusions were also made by Ali (2006). The rice-prawn gher (RPG) farming technique has been institutionalized for over 25 years.
However, the impacts of RPG farming on farm productivity, food security and poverty reduction in southwest Bangladesh have been considerably paid less attention. Therefore, the present study was undertaken to evaluate the impacts of RPG farming on farm productivity, food security and poverty reduction in the southern part of Bangladesh.

\section{Materials and Methods}

\subsection{Farm survey method}

Primary data were used in this study to examine the impacts of rice-prawn gher farming system on farm productivity in the southern part of Bangladesh. The farm survey was carried out during the month of October 2011 based on the agricultural cropping year 2010 in two study villages, Bilpabla (RPG farming) and Chanchra (year-round modern variety -YRMV farming) in Khulna and Jessore districts, respectively. The Bilpabla village was selected intentionally as the people having vast experience on RPG farming system and direct or indirect dependency on various gher-farming activities for their daily livelihood.

On the other hand, Chanchra village was also purposely selected. Farmers in Chanchra usually practice YRMV paddy farming because the farms are located in relatively high altitudes, consequently preventing the adoption of the RPG farming system like Bilpabla in Khulna. MV Boro (BRRIdhan28) paddy is produced during January to April followed by high yielding variety (HYV) T. Aman (BRRIdhan11) paddy during July to December. Likewise, in this study, ninety farmers were randomly selected from Bilpabla and one hundred farmers from Chanchra. Moreover, the socioeconomic data of rice and prawn production were collected through a comprehensive questionnaire.

\subsection{Rice-prawn gher (RPG) farming system in the study area}

The term 'gher' refers to the modification of a rice field to enable the operation of three 
enterprises: prawn (principal enterprise), fish, and modern varieties (BRRIdhan28) of rice. The 'gher' is surrounded by high, wide dikes and contains canals dug at its' inner periphery. During the monsoon season, specifically from June to December, the entire area of the 'gher' is filled with rain-water, and it closely resembles a typical pond. On the contrary, from January to April, the 'gher' naturally dries out with the exception of the canals.

Typically, a 'gher' cycle begins in June. During this time, farmers release freshwater prawn $(M$. rosenbergii) postlarvae into the 'gher'. In preparation of the 'gher', farmers use lime to reduce soil acidity. Throughout the growing period, farmers provide supplementary feed to the prawns (Barmon et al., 2004a). Traditionally, snail meat was used as prawn feed, but contemporary farmers use a wide range of homemade (fishmeal, pulses, beaten rice, wheat bran, rice bran etc.) and commercially available supplementary feeds, to increase production. During May-June, the carp fish fingerlings such as rohu (Labeo rohita), catla (Catla catla), and mrigel (Cirrhina mrigala) are released into the 'gher' and are cultured for nine months. Normally, the density rate of carp fish fingerlings per acre gher plot varies between 10 $\mathrm{kg}$ to $20 \mathrm{~kg}$ depending on the size of carp fingerlings. Usually, no specific supplementary feed is provided to the fishes; leaving them to share the same feed supplied to the prawns. Durinh January to April, the 'gher' is irrigated by water from internal canals by means of either traditional methods (swing basket) and/or pumps, permitting farmers to cultivate MV Boro rice.

\subsection{Cropping patterns of the study villages}

Before the advent of gher farming in Bilpabla, the farmers cultivated only local $A u s$ and broadcast Aus and Aman paddy in swampland and transplant Aman (T. Aman) paddy in the upper lands. The familiar broadcast $A u s$ and Aman paddy have almost disappeared mainly because of siltation of inland rivers and canals, embankments of rivers, and environmental changes. Oil seed crops such as rapeseed, mustard and sesame were produced also in the comparatively high altitude land located in the riverside.

The life cycle of broadcast Aman was longer than the broadcast Aus paddy though the sowing time was same for the both types of paddy. The sowing time of Aus and Aman paddy is in April/May and harvesting time is in August for broadcast aus and December for broadcast Aman. The farmer sowed Aus and Aman seeds together in April/May because after June/July the whole area go under water due to heavy rain and at that time it was not possible to transplant Aman (T. Aman). This production system of local Aus and floating Aman paddy together was locally known as "Domuti".

Gher farming system has changed the cropping patterns dramatically in the study area. The construction of rice-prawn gher farming has created opportunity for crop diversification. Along with prawn and fish, farmers can now cultivate MV Boro paddy on the mid field and vegetables on the dikes of the gher mainly for home consumption. Prior to the gher farming, farmers cultivate oil seeds such as rape, mustard and sesame after the harvest of local broadcast Aman paddy. However, the gher farmers are not able to cultivate oil seeds due to physical construction of gher farming.

The gher farming system has increased vegetables production compared to past. The farmers have also planted fruit trees (coconut, mango, guava, jackfruit, banana, papaya etc.) on the dikes. The production period of prawn and fish starts from May/June to December /January, MV Boro paddy from the end of January to end of April and vegetables throughout the year. 


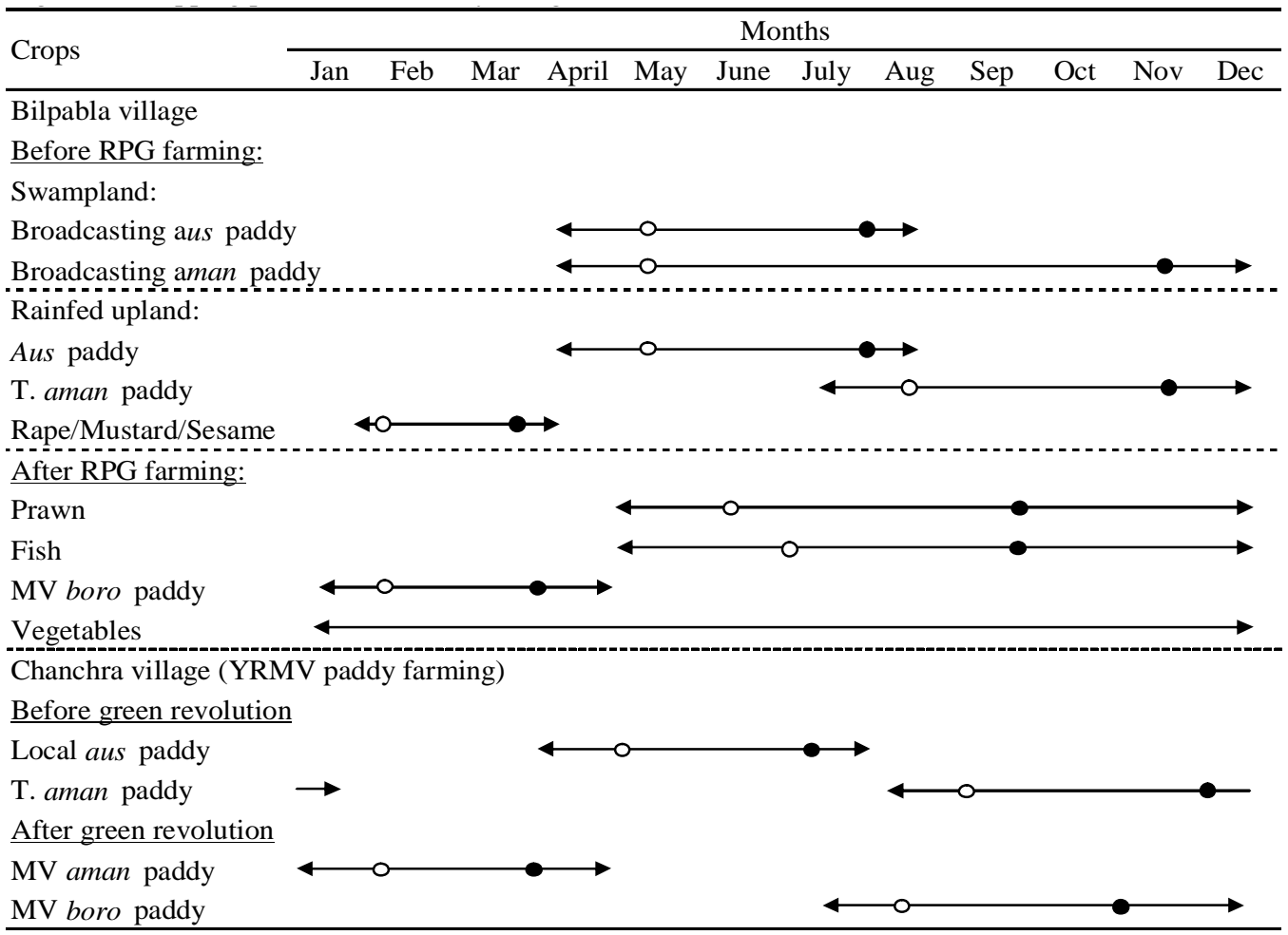

Source: Field survey, 2011.

Notes: 0 indicates the period up until the sowing paddy, and releasing of prawn and fish is carried out.

- indicates harvesting time starts.

Figure 1. Cropping patterns of the study villages

Farmers in Chanchra village usually practice YRMV paddy farming because the farms are located in relatively high altitude level that are not possible to convert into RPG farming system like Bilpabla village in Khulna. MV Boro (BRRIdhan28) paddy is produced during January to April followed by high yielding variety (HYV) T. Aman (BRRIdhan11) paddy during July to December. The cropping system of Chanchra village is also presented in Figure 1.

\section{Results and Discussion}

\subsection{Farm productivity}

As mentioned earlier, green revolution technologies have significant impacts on higher farm productivity, higher input productivity as well as higher yield.

\subsubsection{Comparison of RPG and YRMV paddy farming}

Land productivity mainly depends on several factors such as variety, fertilizer management, insect management, irrigation facilities, and production environment. Production environment plays a significant role on land productivity when MV paddy is produced under different farming systems. Regardless of different farming systems and production environments, farmers produced the same variety of MV Boro paddy under the RPG and YRMV paddy farming systems. Grain yield of paddy was used as a measure for land productivity. 
Table 1 represents yield of MV Boro and Aman paddy under the two farming systems. Yield of MV Boro paddy was significantly higher under RPG farming than YRMV paddy farming system. Yield of MV Boro paddy was also higher (significant) than that of MV Aman paddy within the same YRMV paddy farming. In other words, land productivity was higher in MV Boro paddy production under RPG farming in comparison with MV Boro and Aman paddy production under YRMV paddy farming.

\subsection{Income of RPG and YRMV Paddy Farmers}

\subsubsection{Household income}

Household income and per capita income of the RPG and YRMV farming are presented in Table 2. The table reflects that agricultural income remains the principal source of income for households in the sampled RPG and YRMV paddy farming villages. Farm income of gher farmers was more than five times higher than that of farmers involved in the YRMV paddy farming. The family labor income of RPG farmers was about two times higher than that of YRMV paddy farmers. The main reason behind such results is that the RPG farming system has created self-employment opportunities for the gher farmers in comparison with the YRMV paddy production. Usually, the family members of gher farmer mainly engage in repairing and maintenance of gher dike, mud snail crashing for prawn feed, prawn harvesting in prawn cultivation and transplanting, weeding, and harvesting in paddy cultivation. However, the family off-farm income of RPG farmers was twice time higher than that of YRMV paddy farmers. Since, paddy farming was not a profitable enterprise like RPG farming, the YRMV paddy farmers were engaged in various types of off-farm activities. The agricultural wage income of gher farmers was significantly higher than that of YRMV paddy farmers. The explanation behind this scenario is that farm owners exchange their family labor with others during the prawn-harvesting season. Moreover, throughout the prawn production cycle, family members, themselves, participate in farming.

The income from livestock was again higher for gher farmers compared to that of YRMV paddy farmers. This is a clear indication that the gher farming system has positive impacts on livestock as well. Thus, RPG farmers have gained more agricultural income as well as household income compared to that of YRMV paddy farmers.

\subsubsection{Per Capita household income}

The per capita household income of the RPG (Bilpabla) and YRMV paddy farmers (Chanchra) are represented in Table 2. The table shows that per capita household income of RPG farmers was more than twice as much as that of the YRMV paddy farmers. Therefore, it could be concluded that the RPG farming system has not only increased household income but, also has amplified per capita household income in compared to YRMV paddy farming.

Table 1. Grain yield of MV paddy under two farming systems

\begin{tabular}{lccccc}
\hline \multirow{2}{*}{ Particulars } & \multicolumn{2}{c}{ Farming systems } & \multirow{2}{*}{ Ratio } & \multirow{2}{*}{ t-statistics } \\
\cline { 2 - 3 } \cline { 5 - 6 } Grain yield of Boro paddy (kg/ha) & 5,237 & & 4,791 & & \\
\hline Grain yield of Aman paddy (kg/ha) & $\mathrm{Na}$ & & 4,09 & $9.37^{*}$ \\
\hline
\end{tabular}

Source: Field survey, 2011.

Note: $(1) *$ indicate statistically significant at $1 \%$ level.

(2) Na indicate Not applicable. 
Table 2. Comparison of household income and per capita income of two farming System

\begin{tabular}{lccc}
\hline Particulars & $\begin{array}{c}\text { RPG farming } \\
\text { (Bilpabla village) }\end{array}$ & $\begin{array}{c}\text { YRMV farming } \\
\text { (Chanchra village) }\end{array}$ & Ratio \\
\hline (i) Profit of farming & 125,763 & 23,874 & 5.27 \\
(ii) Opportunity cost family labors & 32,123 & 15,820 & 2.03 \\
(iii) Opportunity cost of land & 15,543 & 6,385 & 2.43 \\
(iv) Agricultural wage & 24,624 & 18,800 & 1.31 \\
(v) Livestock & 22,650 & 18,720 & 1.21 \\
(vi) Off-farm income & 15,830 & 7,599 & 2.09 \\
(vii) Homestead gardening & 2,014 & 279 & 7.22 \\
\hline (i) Household income (taka) & 238,547 & 91,477 & 2.61 \\
\hline (ii) Per capita income (taka) & 54,713 & 21,274 & 2.58 \\
\hline
\end{tabular}

Source: Field survey, 2011 and adopted Barmon 2010.

(i) 1 US $\$=77.75$ taka (April, 2014).

\subsection{Food and nutrition security}

\subsubsection{Basic concepts of food security}

According to the FAO (2008) definition, "food security is a situation that exists when all people, at all times, have physical, social and economic access to sufficient, safe and nutritious food to meet their dietary needs and food preferences for an active and healthy life". In other words, food security prevails if both food supply and demand are sufficient to cover food requirements on a continuous and stable basis. So, the concept of food security mainly concentrates on increasing agricultural production, the availability and access to food. On the other hand, nutrition security emphasizes more on the physiological needs for nutrients and the role of the environment in determining good health and nutrition (Shetty, 2009).

The main dimensions of food security are (i) Production and Availability of Food (ii) Physical and Social Access (iii) Economic Access and (iv) Utilization or Nutrition. The brief explanation of the concept of food security is as follows:

\section{Production and availability of food}

It refers to the availability of sufficient quantities of food, having appropriate quality, which is supplied through domestic production or imports (including food aid).

\section{(i) Physical and social access}

For physical access, a national or an individual has the ability, unimpaired by any physical barrier, to get hold of food. Social access, on the other hand, refers to an individual or household being able to access food by either one or the many other political /communal /familial /socialinstitutional mechanisms.

(ii) Economic access: It refers to an individual or household being able to access food by exercising purchasing power in markets.

(iii) Utilization or nutrition: It refers to both processes and outcomes whereby, food consumed is converted into health, nutrition and well-being.

\subsubsection{Impacts of RPG farming on food security in the study villages}

The concepts or main dimensions of food security is briefly explained in the case of the RPG and YRMV of paddy farming system. The 
impacts of RPG farming system on food security are delineated in Figure 2.

\section{(i) Production and availability of food}

Rice is the staple food of Bangladesh. The main sources of protein are fish, meat and eggs. Referring to the study villages, prawn, fish, paddy and vegetables are cultivated in RPG farming (Bilpabla village) whereas; only MV paddy is produced in YRMV farming (Chanchra village). In RPG farming, prawn is the exclusive exportable item and a portion of MV paddy, fish and vegetable items generally becomes family home consumption. Almost all farmers in Bilpabla village raise cows, ducks and poultry in their home-yards. Straw is the main feed item for nurturing cows and bullocks. As a result, households of Bilpabla village acquire vegetables from their own gher dike; fish from their gher pond; and milk and eggs from raising cows and poultry. However, the households of Chanchra village only get hold of paddy for apportionment of home consumption. Thus, it can be concluded that the households of Bilpabla village supply more food and protein to family members, in comparison to the households of Chanchra village.

\section{(ii) Physical, social and economic access of food}

The households of Bilpabla village have more physical, social and economic access to food compared to the capabilities of households in Chanchra village. As mentioned earlier, prawn is the main exportable item and RPG farming is a more advantageous enterprise compared to YRMV farming. Moreover, on an average, the households of Bilpabla village consume only 60 $70 \%$ of the paddy produced and they sell the remaining $30-40 \%$ in the local markets.

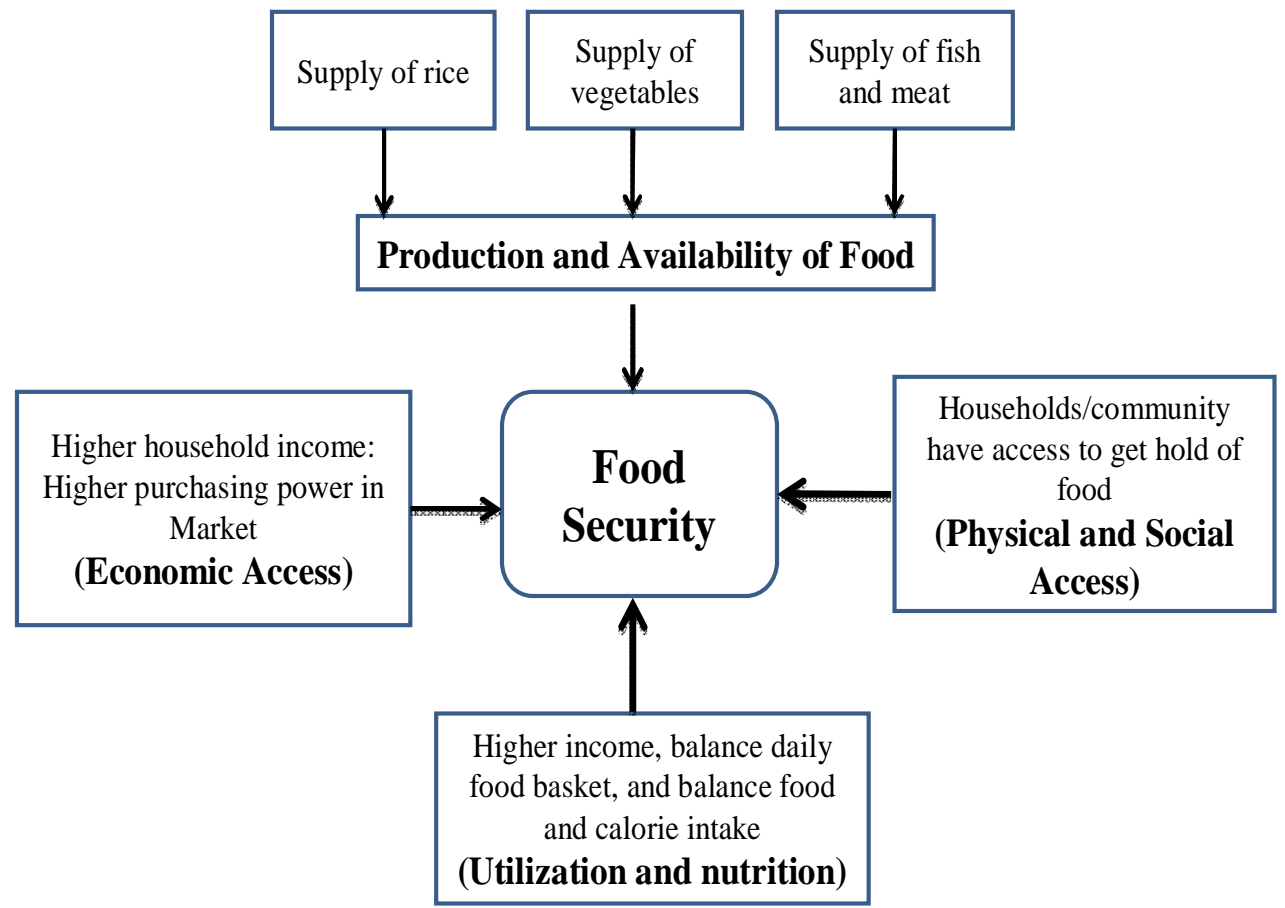

Figure 2. Schematic diagram of the impacts of RPG farming on food security in the locality 
Table 3. Percentage of home consumption and selling of produced paddy in RPG and YRMV farming

\begin{tabular}{lcc}
\hline Types of farming & Consumption (\%) & Selling (\%) \\
\hline RPG farming & $60-70 \%$ & $30-40 \%$ \\
\hline YRMV farming & $90-100 \%$ & $0-10 \%$ \\
\hline
\end{tabular}

Source: Field survey, 2011.

Table 4. Status of poverty incidence (\% of households) in study village

\begin{tabular}{lcc}
\hline Food availability level & RPG farming & YRMV farming \\
\hline Taken 3 meal a day & $90-100 \%$ & $70-80 \%$ \\
\hline Emplyment status & Through out the year & Seasonal \\
\hline
\end{tabular}

Source: Field survey, 2011.

On the contrary, the households of Chanchra village consume almost $90-100 \%$ of their paddy produced, but a few farmers do sell small amounts of paddy only for the purpose of purchasing the food items needed for daily meal (Table 3). As a result, the households of Bilpabla village are physically, socially and economically more solvent than those residing in Chanchra village. In other words, the households of Bilpabla village have more purchasing power to procure more supplementary balanced foods than those of Chanchra village. Therefore, it could be concluded that the RPG farming has significant impacts on the physical, social and economic access (purchasing power) of households than YRMV farming.

\section{(iii) Utilization or nutritional access}

As the household income and per capita income of RPG farming is significantly higher than that of YRMV paddy farming, the households of Bilpabla village are economically more solvent and have more purchasing power relative to the households of Chanchra village. Compared to Chanchra village, households of Bilpabla village obtain ample amounts of balanced food from gher farming and buy supplementary food from local markets for their daily meals. Since, the family members of the households of Bilpabla village have access to more balanced food; their family members acquire a balanced nutrition for good health and well-being, relative to family members of the households of Chanchra village. Therefore, it could be concluded that technologically advanced RPG farming has significant impacts on food security in the study village.

\subsection{Impact on poverty reduction}

The RPG farming system has significant impacts on poverty reduction in Bilpabla village compared to Chanchra village (YRMV paddy farming). The status of poverty incidence in the study villages are showed in Table 4.

Food security and poverty reduction are positively related. The households of Bilpabla village are more food secured compared to Chanchra village. Also, the poverty level of Bilpabla village is lesser than that of Chanchra village. Almost 90-100\% households of Bilpabla village enjoy the "intake of 3 meals a day" status, whereas, only $70-80 \%$ of households in Chanchra village enjoy the equivalent status. Moreover, RPG farming has created additional 
employment opportunities for the people in Bilpabla village compared to YRMV farming in Chanchra village. As the people of Bilpabla village remain employed throughout the year, they have more purchasing power capacity compared to those of Chanchra village. As a result, households of Bilpabla village purchase and consume more balanced foods and calorie intake that help them sustain a good and sound health. Therefore, it could be concluded that the poverty incidence level of households in Bilpabla village is lower than that of Chanchra village (YRMV farming).

\section{Conclusions}

Rice-prawn gher (RPG) is a locally adopted, developed and integrated farming system in southwestern Bangladesh. The findings of the study indicate that the farm productivity (yield/ha) of MV paddy production under RPG farming is significantly higher than that of MV boro paddy production under YRMV paddy farming in Bangladesh. The household income and per capita income of the households in RPG farming exceeded by more than double than that of households practicing YRMV paddy farming. The households of RPG farming are enjoying more rice, other staple foods and proteins, fruits, milks, eggs etc. compared to YRMV farming. A portion of produced paddy $(60-70 \%)$ is enough to meet the demand for home family consumption and the remaining 30-40\% of paddy is sold off in the local markets for shopping of food items needed in their daily meal. In other words, the purchasing power of households in Bilpabla village was greater than that of Chanchra village. As a result, the households of Bilpabla village consume more balanced food, and obtain more protein and calorie intake from their daily meal, in comparison to the households designated in Chanchra village. The households of Bilpabla village have the advantage over the households of Chanchra village in terms of more physical, social and economic access which provides the ability to attain food. Recalling the fact that food security and poverty reduction are positively related, we can see that the households of
Bilpabla village have more food security, which enables them to achieve a lower poverty incidence level compared to the residence of Chanchra village. Therefore, it could be concluded that RPG farming has significant impacts on farm productivity, food security and poverty reduction in the study villages.

\section{References}

Ali, A. M. S. 2004. Technological Change in Agriculture and Land Degradation in Bangladesh: A Case Study. Land Degradation \& Development, 15: 283298.

Ali, A. M. S. 2006. Rice to Shrimp: Land Use/Land cover Changes and Soil Degradation in Southwestern Bangladesh, Land Use Policy, 23:421435.

Aftabuzzaman, M. 1998. Sustainable Environment-Friendly aquaculture. In Centre for Policy Dialogue, Environmental Consequences of Export Oriented Shrimp Culture in Bangladesh, CPD Dialogue Report No. 18. Centre for Policy Dialogue, Dhaka, Bangladesh.

Asaduzamman, M., Toufique K. A. 1998. Rice and fish: "Environmental Dilemmas of Development in Bangladesh" in Growth or Stagnation? A review of Bangladesh's Development 1996, Center for Policy Dialogue, University presses Ltd. Dhaka (mimeo).

Ahmed, N., Allison E. H. and Muir, J. F. 2008a. Using the Sustainable Livelihoods Framework to Identify Constraints and Opportunities to the Development of Freshwater Prawn Farming in Southwest Bangladesh. World Aquaculture Society, 39:598-611.

Ahmed, N., Brown, J. H. and Muir, J. F. 2008 b. Freshwater Prawn Farming in Gher Systems in Southwest Bangladesh. Aquaculture Economics \& Management, 12:207-223. 
Ahmed, N., Demaine, H. and Muir, J. F. 2008c. Freshwater Prawn Farming in Bangladesh: History, Present Status and Future Prospects. Aquaculture Research, 39:806-819.

Ahmed, N., Garnett, S. T., 2010a. Sustainability of Freshwater Prawn Farming in Rice Fields in Southwest Bangladesh. Journal of Sustainable Agriculture, 34(6):659-679.

Ahmed, N., Allison, E. H. and Muir., J. F. 2010b. Rice Fields to Prawn Farms: A Blue Revolution in Southwest Bangladesh? Aquaculture International, 18:555-574.

Ahmed N, Lecouffe C, Allison E. H. and Muir, J.F. 2009. The Sustainable Livelihoods Approach to the Development of Freshwater Prawn Marketing Systems in Southwest Bangladesh. Aquaculture Economics \& Management, 13:246-269.

Barmon, B. K., Kondo, T. and Osanami, F. 2004a. Labor Demand for Rice Prawn Gher Farming in Bangladesh: A Case Study of Khulna District. The Review of Agricultural Economics, 60:273-287.

Barmon, B. K., Kondo, T. and Osanami, F. 2004b. Impactss of Rice Prawn Gher Farming on Cropping Patterns, Land Tenant System, and Household Income in Bangladesh: A Case Study of Khulna District. Asia-Pacific Journal of Rural Development, (APJORD), 14(1):10-28.

Barmon, B. K., Kondo, T. and Osanami, F. 2004c. Impacts of Rice-Prawn Gher Farming on Agricultural and Household Income in Bangladesh: A Case Study of Khulna District. Journal of Bangladesh Studies (JBS) 6(1\&2):51-61.

Barmon, B. K., Kondo, T. and Osanami, F. 2005. Historical Background and Diffusion Process of Rice-prawn Gher Farming in Bangladesh-A Case Study of Khulna District. The Review of Agricultural Economics, 61:85-100.
Barmon, B. K., Kondo, T. and Osanami, F. 2007. Women's Participation in Rice Prawn Gher Farming in Bangladesh, International Journal of Women, Social Justice and Human Rights (IJWSJHR) 2(1):1-15.

Barmon, B. K., Kondo, T. and Osanami, F. 2008. Inputs Used in Modern Variety (MV) Paddy Farming and Household Income: A Comparative Study of Rice-prawn Gher and Year-round MV Paddy Farming System in Bangladesh. The Review of Agricultural Economics, 63:1-18.

Barmon, B. K., Kondo, T. and Osanami, F. 2007. Economic Evaluation of Rice-Prawn Gher Farming System on Soil Fertility for Modern Variety of Rice Production in Bangladesh. Asia-Pacific Journal of Rural Development (APJORD), 17(1):67-81.

Barmon B. K., Kondo T. and Osanami, F. 2008. Water Productivity of HYV Variety of Paddy Production: Rice Prawn and Yearround Paddy Farming Systems in Bangladesh. Asia Pacific Journal of Rural Development, 18:99-118.

Barmon, B. K., Kondo, T., Yamaguchi, J., and Osanam, F. 2010. Rice-prawn Farming System: Impacts on Soil Quality and Land Productivity of Modern Variety Paddy Production in Bangladesh. Asian Journal of Agriculture and Development, 7(2): 4966.

Bhattacharya, D., Rahman, M. and Khatun, F. 1999. Environmental Impacts of Structural Adjustment Policies: The Case Export Oriented Shrimp Culture in Bangladesh, Centre for Policy Dialogue (CPD), Dhaka.

Chowdhury, M. A., Shivakoti, G. and Salequzzaman, M. 2006. A Conceptual Framework for the Sustainability Assessment Procedures of the Shrimp Aquaculture Industry in Bangladesh. International Journal of Agricultural 
Resource, Governance and Ecology, 5(2/3):162-184.

Datta, D. K. 2001. Ecological Role of Fresh Water Apple Snail Pila globosa and the Consequences of its over-harvesting from beel Ecosystem of Bagerhat and Gopalgonj district. A Study Report.

FAO, 2008. Food and Agricultural Organization, available http://www.fao.org/wfs/index_en.htm

Islam, M. S. 2008. From Pond to Plate: Towards a Twin-driven Commodity Chain in Bangladesh Shrimp Aquaculture, Food Policy, 33:209-223.

Islam, M. S., Milstein, A., Wahab, M. A., Kamal, A. H. M. and Dewan, S. 2005. Production and Economic Return of Shrimp Aquaculture in Coastal Ponds of Different Sizes and with Different Management Regimes. Aquaculture International, 13:489-500.

Ito, S. 2002. From Rice to Prawn: Economic Transformation and Agrarian Structure in Rural Bangladesh. Journal of Peasant Study, 29:47-70.

Ito, S. 2004. Globalisation and Agrarian Change: A Case of Freshwater Prawn Farming in Bangladesh. Journal International Development, 16:1003-1013.

Islam, S. 2001. Study on beel fisheries in gher farming areas under Bagerhat district. Greater Options for Local Development through Aquaculture (GOLDA) Project, CARE-Bangladesh.

Islam, M. S. 2003. Socioeconomic Impacts of Alternate Shrimp-shrimp-crop Farming in Bangladesh In: 'Environmental and socioeconomic impacts of shrimp aquaculture in Bangladesh (ed) M.A. Wahab, Technical proc. pp. 61-78. BAUNORAD Workshop, BRAC Centre, Dhaka, Bangladesh, Bangladesh Agricultural University, Mymensigh, Bangladesh, $101 \mathrm{p}$.

Kendrick, A. 1994. The Gher Revolution: The Social Impactss of Technological Change in Freshwater Prawn Cultivation in Southern Bangladesh. The Report of a Social Impacts Assessment Prepared for CARE International in Bangladesh with Support from the Bangladesh Aquaculture and Fisheries Resource Unit (BAFRU).

Nijera Kori. 1996. The Impacts of Shrimp Cultivation on Soils and Environment in Paikgacha Region, Khulna (Limited to polders 20, 21, 22, 23, and 24).

Rahman, M. 1998. Shrimp Culture, Global Compulsions and Policy Options for Environmental Protection. Centre for Policy Dialogue (CDP). Environmental Consequences of Export Oriented Shrimp Culture in Bangladesh: Reforms and Changes. A Workshop Report.

Rahman, S., Barmon, B. K. and Ahmed, N. 2011. Diversification Economies and Efficiencies in a 'Blue-green Revolution' Combination: A Case Study of Prawncarp-rice Farming in the 'gher' System in Bangladesh. Aquaculture International, 19(4):665-682.

Rahman, S. and Barmon, B. K. 2012. Energy Productivity and Efficiency of the 'Gher' (Prawn-fish-rice) Farming System in Bangladesh. Energy, 43:293-300.

Shetty, P. 2009. Incorporating Nutritional Considerations when Addressing Food Insecurity. Food Science, 1:431-440. 